\title{
FLORA DE GRÃO-MOGOL, MINAS GERAIS: SANTALACEAE ${ }^{1}$
}

\author{
DELMIRA C. SILVA*, MARIA A. FARINACCIO \& RAMIRO G.V. CAMACHO** \\ Departamento de Botânica, Instituto de Biociências, Universidade de São Paulo, \\ Caixa Postal 11461, 05422-970 - São Paulo, SP, Brasil. \\ * endereço atual: Departamento de Ciências Biológicas, Universidade Estadual de Santa Cruz, \\ 45650-000 - Ilhéus, BA, Brasil. \\ ** endereço atual: Departamento de Ciências Biológicas, Universidade Estadual do Rio Grande do Norte, \\ R. Almino Afonso, 478, 59610-210 - Mossoró, RN, Brasil.
}

De Candolle, A.L.P.P. 1857. Santalaceae. In Prodromus systematis naturalis regni vegetabilis V. Masson. Paris, vo1. 14, p. 619-672.

De Candolle, A.L.P.P. 1860. Santalaceae. In C.F.P. Martius \& A.W. Eichler (eds.) Flora brasiliensis. Frid. Fleischer. Leipzig, vol. 5, pars 1, p. 101-104.

Furlan, A. \& Arrais, M.G.M. 1989. Flora da Serra do Cipó, Minas Gerais: Santalaceae. Bol. Bot. Univ. São Paulo 11: 81-83.

\section{Thesium L.}

Ervas a arbustos, freqüentemente parasitas de raízes. Folhas inteiras, alternas, muito reduzidas. Flores monoclinas, monoclamídeas, actinomorfas, infudibuliformes a hipocrateriformes; sépalas (4)5, unidas na base, tubo adnato ao ovário, persistentes ou tardiamente decíduas; estames isômeros, opostos aos segmentos do perigônio, anteras bitecas, rimosas; ovário ínfero, unilocular; disco geralmente indistinto; estigma obtuso ou capitado; óvulos 3-4, pêndulos, placentação basal ou central-livre. Fruto noz, elipsóide, apenas uma semente desenvolvida.

\subsection{Thesium brasiliense A.DC., Prodr. 14: 671. 1857.}

Subarbusto glabro, 23-33 cm alt., ramos prostados a eretos, angulosos, estriados, verde-amarelados a alaranjados, bastante ramificados, às vezes lenticelados. Folhas escamiformes, lanceoladas, glabras, 1-1,5 mm compr., ca. 0,7 mm larg., apressas aos ramos, nervura única, prolongada em estria no ramo. Inflorescência em espiga simples, brácteas lanceoladas, ápice agudo. Flores creme a verde-amareladas; sépalas 5 , espessadas, valvares, ca. $0,3 \mathrm{~mm}$ compr., pubérulas somente ao longo da margem interna, ápice cuculado; estames 5; placentação central-livre. Fruto 1-2 mm diâm., com nervuras salientes. (fig. 1. A-E)

\begin{abstract}
Cordeiro et al. CFCR 11490 (SPF); Harley et al. CFCR 6525 (SPF); Meguro et al. CFCR 9026 (SPF); Pirani et al. CFCR 12528 (SPF).
\end{abstract}

Sudeste ao sul do Brasil, geralmente em campos. Em Grão-Mogol, é encontrada entre rochas, em solos arenosos, em altitudes que variam de 900 a $1200 \mathrm{~m}$. Gênero essencialmente africano, para o Brasil também é citado T. aphyllum Mart. Porém, a separação dessas duas espécies é problemática (Furlan \& Arrais 1989). O material estudado de GrãoMogol apresenta características intermediárias entre essas espécies, questionando-se a consistência da manutenção de dois táxons. Optou-se então por empregar $T$. brasililiense, levando-se em consideração a prioridade de publicação.

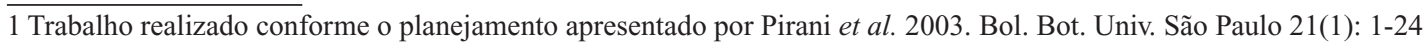




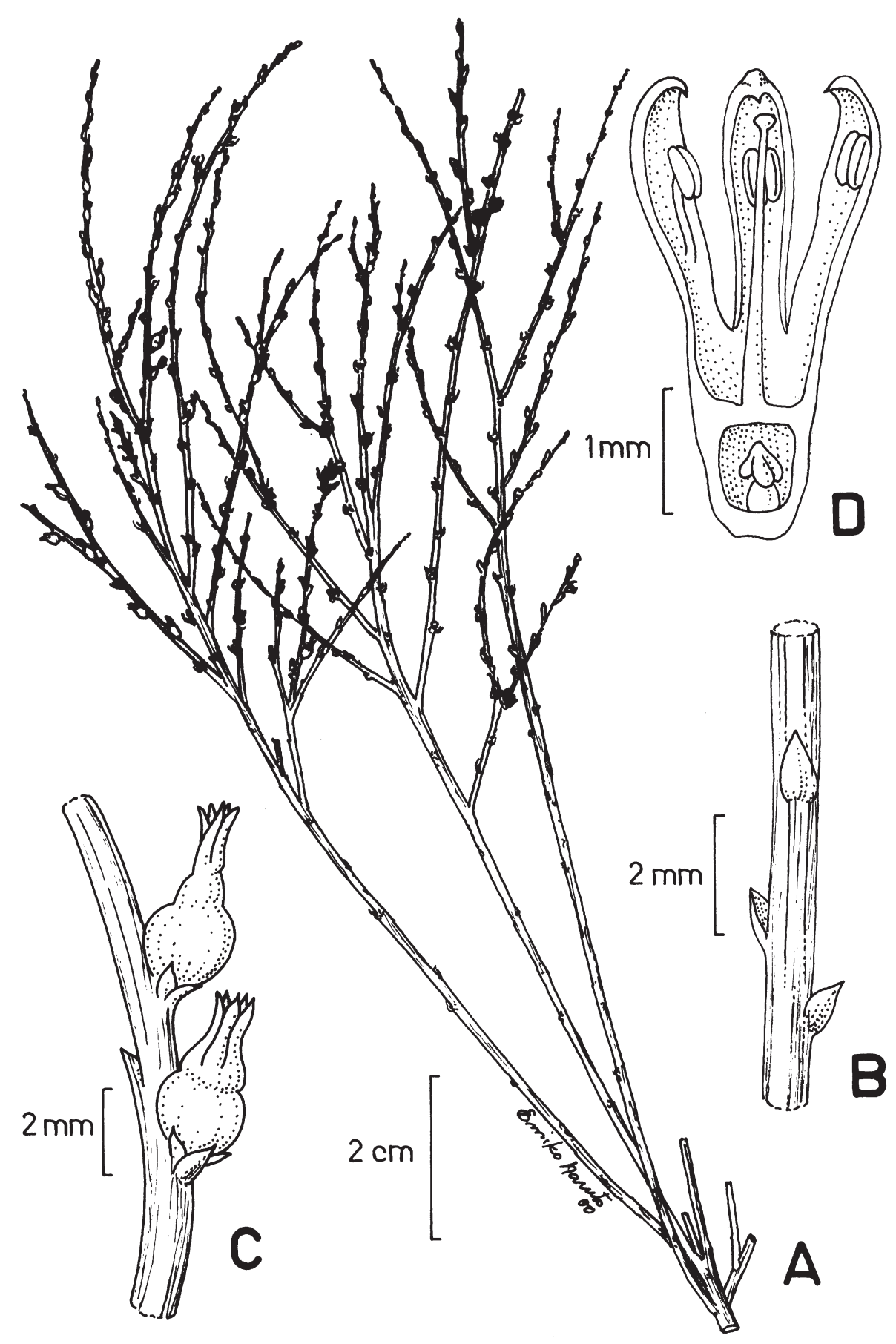

Fig. 1. SANTALACEAE. Thesium brasiliense: A. Ramo florífero; B. Detalhe de ramo com folhas escamiformes; C. Trecho de espiga com dois frutos; D. Flor, corte longitudinal (baseado em Furlan \& Arrais 1989). 